\title{
Pregnancy-induced Cushing's syndrome with an adrenocortical adenoma overexpressing LH/hCG receptors: a case report
}

\author{
Shaohua $\mathrm{Li}^{\dagger}$, Chen Yang ${ }^{\dagger}$, Jing Fan, Yao Yao, Xiaomei Lv, Ying Guo and Shaoling Zhang ${ }^{*}$
}

\begin{abstract}
Background: Pregnancy-induced Cushing's syndrome (CS) with an adrenocortical adenoma overexpressing luteinizing hormone (LH)/human choriogonadotropin (hCG) receptors (LHCGR) has been rarely reported in the literatures. This peculiar condition challenges the canonical diagnosis and management of CS.

Case presentation: A 27-year-old woman (G2POA1) presented at 20 weeks gestational age (GA) with overt Cushingoid clinical features. Adrenocorticotropic hormone (ACTH)-independent CS was diagnosed based on undetectable ACTH and unsuppressed cortisol levels by dexamethasone. Magnetic resonance imaging (MRI) scanning without contrast revealed a left adrenal nodule while pituitary MRI scanning was normal. A conservative treatment strategy of controlling Cushingoid comorbidities was conducted. At 36 weeks GA, a caesarean operation was performed and a live female infant was delivered. At 8 weeks after parturition, our patient achieved normalization of blood pressure, blood glucose, serum potassium, and urinary cortisol level spontaneously. During non-pregnancy period, stimulation testing with exogenous hCG significantly evoked a cortisol increase. The woman underwent resection of the adrenal tumor at 6 months after parturition. Immunohistochemistry (IHC) showed the tumor tissue that stained positive for luteinizing hormone (LH)/human choriogonadotropin (hCG) receptor (LHCGR), whereas negative for both melanocortin 2 receptor (MC2R) and G protein-coupled receptor-1 (GPER-1).
\end{abstract}

Conclusions: Stimulation test with exogenous hCG after parturition is necessary for the diagnosis of pregnancyinduced CS. LHCGR plays an essential role in the pathogenesis of this rare condition.

Keywords: Cushing's syndrome, Pregnancy, LHCGR, Cyclic adenosine monophosphate (CAMP) signaling pathway

\section{Background}

Pregnancy-induced Cushing's syndrome (CS) is rare, with a total of 15 cases reported in the world literature to our knowledge [1-15], and only two of those patients were secondary to an adrenal adenoma overexpressing luteinizing hormone (LH)/human choriogonadotropin

\footnotetext{
*Correspondence: zhshaol@mail.sysu.edu.cn; sysuzs188@163.com ${ }^{\dagger}$ Shaohua Li and Chen Yang contributed equally to this work. Department of Endocrinology, Sun Yat-sen Memorial Hospital, Sun Yat-sen University, 107 Yanjiang West Road, Guangzhou 510120, China
}

(hCG) receptors (LHCGR) [12, 14]. Recently, hCGdependent LHCGR activation coupled to cyclic adenosine monophosphate (cAMP) pathway has been considered to play an important role in pregnancy-induced CS $[14,15]$. In 35-65\% CS patients with cortisol-producing adrenal adenomas (CPA), somatic mutations of cAMP dependent protein kinase A (PRKACA) has been identified to constitutively activate cAMP/protein kinase A (PKA) pathway [16, 17]. We herein report a new case of pregnancy-induced CS with an adrenocortical adenoma.

(c) The Author(s). 2020 Open Access This article is licensed under a Creative Commons Attribution 4.0 International License, which permits use, sharing, adaptation, distribution and reproduction in any medium or format, as long as you give appropriate credit to the original author(s) and the source, provide a link to the Creative Commons licence, and indicate if changes were made. The images or other third party material in this article are included in the article's Creative Commons licence, unless indicated otherwise in a credit line to the material. If material is not included in the article's Creative Commons licence and your intended use is not permitted by statutory regulation or exceeds the permitted use, you will need to obtain permission directly from the copyright holder. To view a copy of this licence, visit http://creativecommons.org/licenses/by/4.0/ The Creative Commons Public Domain Dedication waiver (http://creativecommons.org/publicdomain/zero/1.0/) applies to the data made available in this article, unless otherwise stated in a credit line to the data. 
Considering that elevated estrogen during pregnancy could also potentially contribute to the activation of cAMP pathway through reacting on corresponding Gprotein-coupled receptor (GPCR), immunohistochemistry $(\mathrm{IHC})$ was performed on the adrenal adenoma tissue of our case to detect the expression of $\mathrm{G}$ proteincoupled receptor-1 (GPER-1), as well as LHCGR and melanocortin 2 receptor (MC2R). On the basis of previous findings and our IHC results, we discuss the underlying pathogenesis of this rare condition.

\section{Case presentation}

A 27-year-old woman (G2P0A1) presented at 20 weeks gestational age (GA) with overt Cushingoid clinical features and was transferred to our hospital at 28 weeks GA. On physical examination, she had moon facies, acne, dorsocervical fat pad, violaceous striae and edema of both lower limbs. She was found to be hypertensive with a blood pressure of 140-150/70-90 mmHg. Laboratory examinations revealed hypokalemia with repeated low serum potassium measurements of 2.36, 2.99 and $3.13 \mathrm{mmol} / \mathrm{L}$ (reference range $3.5-5.5 \mathrm{mmol} / \mathrm{L}$ ), and evidence of gestational diabetes mellitus (GDM) with a fasting plasma glucose of $7.24 \mathrm{mmol} / \mathrm{L}$ (reference range < $5.1 \mathrm{mmol} / \mathrm{L}$ ) and oral glucose tolerance test (OGTT) $2 \mathrm{~h}$ plasma glucose of $12.27 \mathrm{mmol} / \mathrm{L}$ (reference range $<8.5$ $\mathrm{mmol} / \mathrm{L}$ ). The menarche had occurred at age 16 , and her menstrual cycles were irregular, occurring every 36 days, with moderate menstrual flow, lasting for 8 to 9 days. Her last pregnancy ended up with an abortion, but no Cushingoid symptoms or signs were observed and she was not diagnosed GDM or hypertension during prior pregnancy. Her past history was negative for hypertension, diabetes and hypercortisolism, but her father suffered from hypertension.

Preliminary examinations indicated hypercortisolism, including multiple elevated $24 \mathrm{~h}$ free urinary cortisol (24 h UFC) measurements of 2611.0 and $2590.0 \mathrm{nmol} / 24 \mathrm{~h}$ (reference range 153.2-789.4 nmol/24 h), midnight salivary cortisol 61.95 and $33.04 \mathrm{nmol} / \mathrm{L}$ (reference range $0.00-10.40 \mathrm{nmol} / \mathrm{L}$ ) and loss of normal diurnal rhythm (morning plasma cortisol $924.01 \mathrm{nmol} / \mathrm{L}$ and midnight plasma cortisol $959.39 \mathrm{nmol} / \mathrm{L}$ ). Further inspections were consistent with the diagnosis of adrenocorticotropic hormone (ACTH)-independent CS: $1 \mathrm{mg}$ desamethasone overnight suppression test (DST) showed lack of cortisol suppression, along with repeated findings of undetectable serum ACTH concentrations $(<5 \mathrm{pg} / \mathrm{ml}$ at 8:00 AM, reference range $0-46 \mathrm{pg} / \mathrm{ml})$. Magnetic resonance imaging (MRI) scanning without contrast revealed a left adrenal nodule measuring $2.0 \mathrm{~cm}$ in diameter (Fig. 1), while pituitary MRI scanning was normal. Contrast on hormonal status at each stage of the patient was shown in Table 1.

Our patient did not receive specific treatment of hypercortisolism and a conservative treatment strategy was conducted. The maintenance of pregnancy was under close monitoring of blood pressure and satisfactory management of blood glucose by insulin. Sylvite supplementary treatment was adopted to remedy

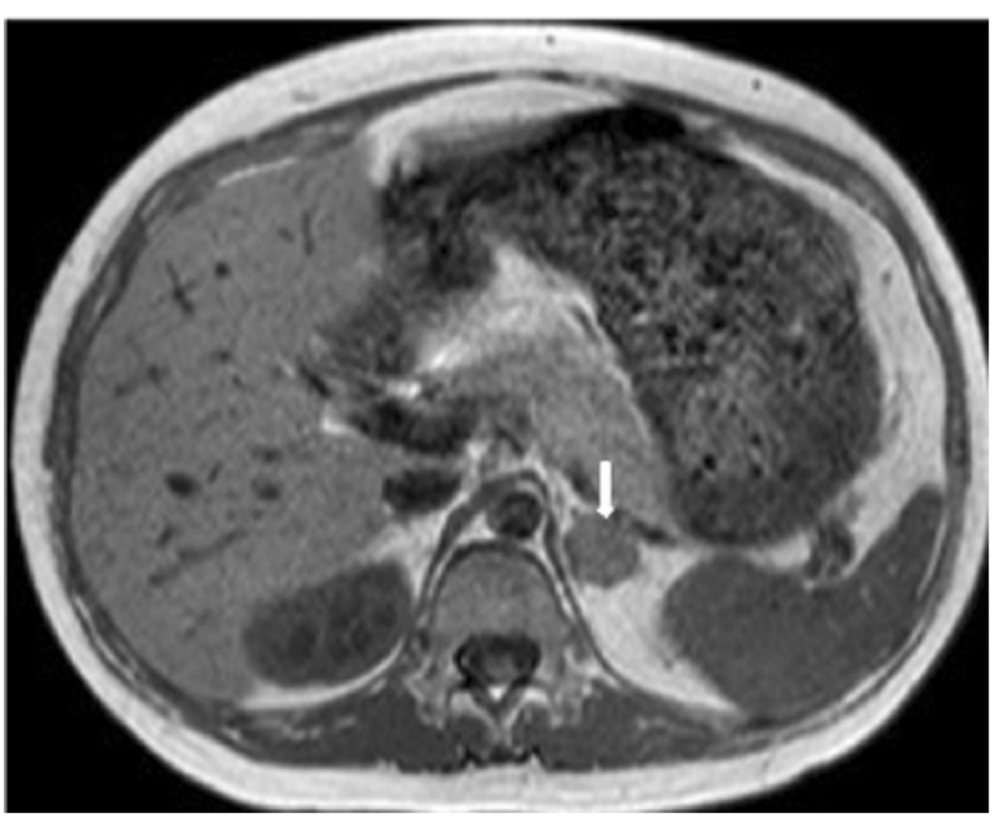

Fig. 1 Adrenal magnetic resonance image (MRI) without contrast of the patient. Adrenal MRI showed a left adrenal nodule measuring $2.0 \mathrm{~cm}$ in diameter (arrow) 
Table 1 Contrast on hormonal status at each stage of the patient

\begin{tabular}{|c|c|c|c|c|}
\hline Laboratory assessment & Week 28 of pregnancy & Week 35 of pregnancy & 3 days after parturition & 8 weeks after parturition \\
\hline \multicolumn{5}{|l|}{$24 \mathrm{~h}$ UFC/(nmol/24 h) } \\
\hline Reference range & $153.2-789.4$ & 153.2-789.4 & $153.2-789.4$ & 153.2-789.4 \\
\hline Day 1 & 2611.0 & 4808.0 & 1650.0 & 723.5 \\
\hline Day 2 & 2590.0 & 4598.0 & - & 547.0 \\
\hline \multicolumn{5}{|c|}{ Midnight Salivary Cortisol/(nmol/L) } \\
\hline Reference range & $0.00-10.40$ & $0.00-10.40$ & $0.00-10.40$ & $0.00-10.40$ \\
\hline Day 1 & 61.95 & 51.00 & - & 9.75 \\
\hline Day 2 & 33.04 & 36.86 & - & - \\
\hline \multicolumn{5}{|l|}{ Diurnal rhythm } \\
\hline $\begin{array}{l}\text { Reference range } \\
\text { (Plasma Cortisol at 8:00 AM) }\end{array}$ & $118.60-618.00$ & $118.60-618.00$ & $118.60-618.00$ & $118.60-618.00$ \\
\hline $\begin{array}{l}\text { Day 1: 8:00 AM- } \\
\text { 4:00 PM- } \\
\text { 12:00 PM }\end{array}$ & $924.01-733.26-959.39$ & 779.05-840.11-1010.46 & $538.24-479.18-537.80$ & $314.46-236.28-224.07$ \\
\hline \multicolumn{5}{|l|}{ DEXA, 1 mg, 12:00 PM } \\
\hline Day 2: 8:00 AM & 872.34 & - & - & 286.64 \\
\hline \multicolumn{5}{|l|}{ Serum ACTH/(pg/ml) } \\
\hline Reference range & $0-46$ & $0-46$ & $0-46$ & $0-46$ \\
\hline 8:00 AM & $<5$ & $<5$ & 9 & $<5$ \\
\hline
\end{tabular}

$24 h$ UFC $24 \mathrm{~h}$ free urinary cortisol, DEXA desamethasone, $A C T H$ adrenocorticotropin

hypokalemia. At 35 weeks GA, her cortisol level displayed a tendency to rise up with elevated $24 \mathrm{~h}$ UFC reaching to $4808.0 \mathrm{nmol} / 24 \mathrm{~h}$. At the request of the patient and her family, the patient underwent vaginal trial production at 36 weeks GA. Given that she developed worsening hypertension (blood pressure 154/103 $\mathrm{mmHg}$ ) under the application of oxytocin for hastening parturition, a caesarean operation was performed and a live female infant was delivered (weighing $2820 \mathrm{~g}, 48 \mathrm{~cm}$ in length, Apgar 10 at $1 \mathrm{~min}, 10$ at $5 \mathrm{~min}$ ). The infant suffered from hypoglycemia and required admission to the neonatal unit. At 3 days after parturition, the plasma cortisol level plummeted to normal, but elevated $24 \mathrm{~h}$ UFC and the absence of normal diurnal rhythm still existed. Of note, the serum ACTH rose up slightly (9 pg/ $\mathrm{ml}$ at $8 \mathrm{am}$ ). At 5 days after parturition, the woman and the infant discharged from hospital in good condition with no clinical evidence of adrenal insufficiency.

At 8 weeks after parturition, our patient achieved normalization of blood pressure, blood glucose, serum potassium, and cortisol level spontaneously. However, loss of normal diurnal rhythm, lack of cortisol suppression by DST and undetectable serum ACTH remained. At 6 months post-partum, stimulation testing with exogenous hCG (10,000 IU) elicited increased cortisol level (basal plasma cortisol $287.69 \mathrm{nmol} / \mathrm{L}$ increased to $532.99 \mathrm{nmol} / \mathrm{L}$ during the test, as shown in Table 2). As scheduled, the woman underwent resection of the adrenal tumor and routine glucocorticoid supplementation was conducted in post operation period. IHC was performed on the tumor tissue to detect the expression of LHCGR, MC2R and GPER-1 (Fig. 2).

\section{Discussion and conclusions}

Transient pregnancy-induced CS is quite rare and 15 cases were reported in the world literature to our knowledge [1-15]. Symptoms and signs of hypercortisolism only arise during pregnancy and remit spontaneously after delivery or abortion. This peculiar disorder challenges the canonical diagnosis of CS due to changes in the hypothalamic-pituitary-adrenal (HPA) axis during pregnancy [13] and provides a unique insight into the underlying molecular pathogenesis of adrenal pathological alterations subsequent to aberrant activation of specific receptors.

Table 2 The result of stimulation testing with exogenous hCG

\begin{tabular}{llll}
\hline $\begin{array}{l}\text { Time post hCG } \\
\text { Administration } \\
\text { (hours) }\end{array}$ & $\begin{array}{l}\text { Serum } \\
\text { hCG } \\
(\mathrm{IU} / \mathrm{L})\end{array}$ & $\begin{array}{l}\text { Plasma } \\
\text { Cortisol } \\
(\mathrm{nmol} / \mathrm{L})\end{array}$ & $\begin{array}{l}\text { Serum } \\
\text { ACTH } \\
(\mathrm{pg} / \mathrm{ml})\end{array}$ \\
\hline 0 & 4.82 & 287.69 & $<5$ \\
8 & 85.68 & 448.69 & $<5$ \\
24 & 116.36 & 458.90 & $<5$ \\
36 & 79.93 & 532.99 & $<5$ \\
48 & 67.60 & 435.82 & $<5$ \\
72 & 37.34 & 350.62 & 6 \\
\hline
\end{tabular}

hCG human choriogonadotropin 

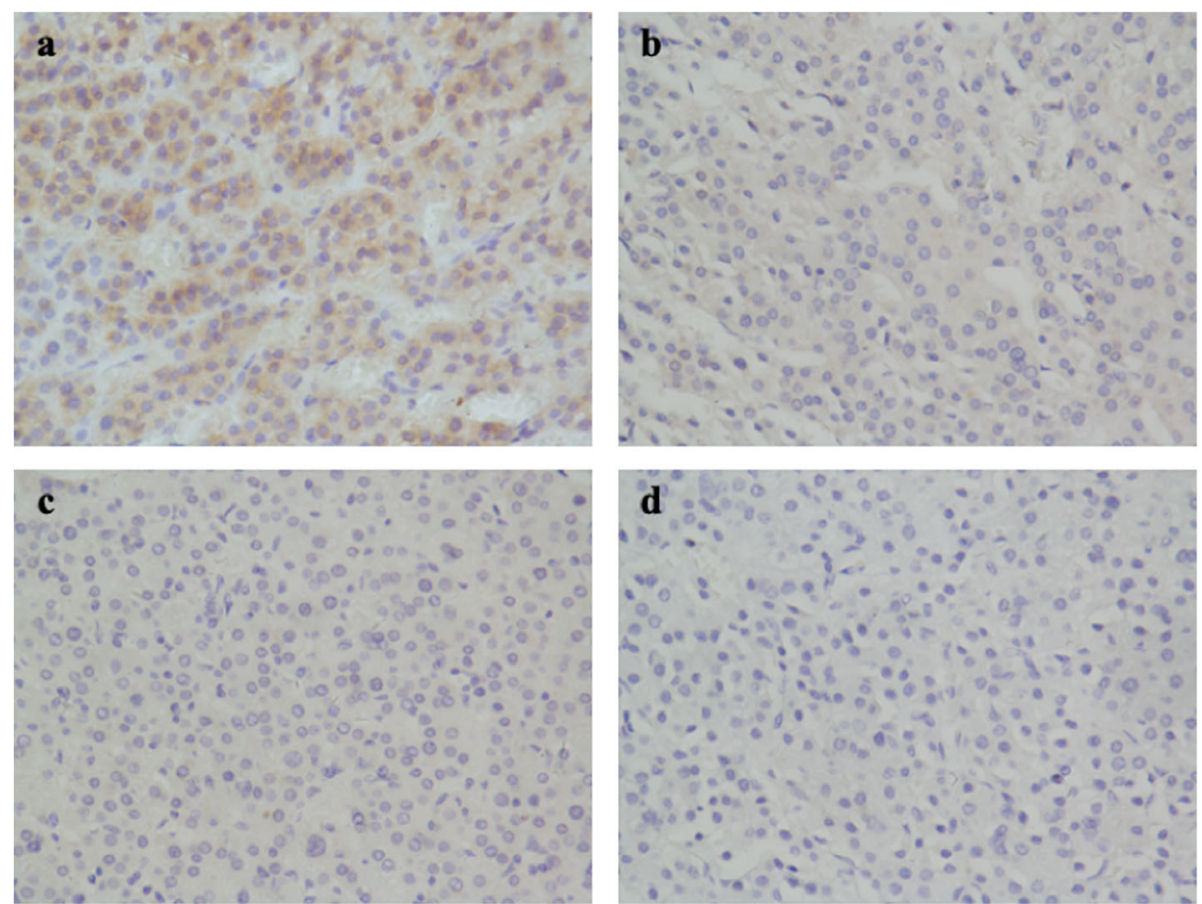

Fig. 2 Immunohistochemical findings, magnification $\times$ 400. Immunohistochemistry showed the adrenal adenoma tissue that stained positive for LHCGR (a), and negative for MC2R (b), GPER-1 (c). Negative controls omitted primary antibody (d)

Despite the marked clinical symptoms and physical signs of hypercortisolism, it is hard to distinguish CS from nonpathologic hypercortisolism during normal pregnancies. The up-regulated HPA axis function in pregnancy is associated with placental ACTH and the increased hepatic synthesis of corticosteroid-binding globulin (CBG) stimulated by elevated circulating estrogens. Compared to nonpregnancy controls, the plasma cortisol in pregnancy is 2- to 3- fold increased, while mean $24 \mathrm{~h}$ UFC is elevated at least $180 \%$ [18]. Since UFC excretion is normal in the first trimester, only up to 2to 3 -fold the upper limit of normal values of UFC in the second or third trimester is recommended as a diagnostic indicator for CS in pregnant women [19]. Meanwhile, loss of normal diurnal rhythm remains reliable as a marker of CS during pregnancy, for the circadian rhythm of cortisol is preserved in normal pregnancy. Moreover, salivary cortisol level should be considered as a meaningful criterion to identify CS in pregnancy in the initial testings [20], because there is no significant variation in salivary cortisol during pregnancy, albeit in a small number of women evaluated. Whereas, DST has an increasing potential to be false-positive because the response of cortisol level to dexamethasone is blunted in pregnancy [18]. In our case, serum ACTH level was continuously undetectable until 3 days post-partum it bounced to $9 \mathrm{pg} / \mathrm{ml}$, whereas it was still undetectable even 8 weeks post-partum. Typical manifestations with more than 3-fold increase of $24 \mathrm{~h}$ UFC, a 5-fold increase of midnight salivary cortical, no response to DST and the suppressed ACTH levels made the diagnosis of ACTH-independent CS unequivocal. Furthermore, the notable withdrawal of hypercortisolism after parturition and the positive stimulation testing with exogenous hCG injection were explicit diagnostic characteristics of hCGmediated hypercortisolism.

Although rare, CS in pregnancy is associated with significant maternal and fetal complications [21] and the management of this disorder remains challenging. Owing to its safety and effectiveness, surgical management, ideally during the second trimester [13], has been recommended as the most favorable option for treatment of both pituitary and adrenal CS during pregnancy [22]. If surgery is contraindicated or must be delayed, treatment with steroidogenesis inhibitors, usually with metyrapone, can be an alternative [22]. Metyrapone has been shown to control hypercortisolism effectively in most instances [23], despite its adverse effects including hypertension, worsening of preeclampsia and the risk of affecting fetal adrenal steroid synthesis since it can cross the placenta [24]. In our case, the patient was managed conservatively by controlling Cushingoid comorbidities and achieved satisfactory management of blood pressure and blood glucose, given that the adrenal mass was determined by MRI late in the third trimester. After parturition, the woman underwent resection of the adrenal 
tumor. Therefore, the proper treatment strategy for the management of this rare condition should be individualized for each patient to improve outcome for both mother and fetus.

In the literature, we found two other cases of pregnancy-induced CS with a cause of an adrenal tumor overexpressing LHCGR $[12,14]$. In our case, IHC staining for LHCGR on the adrenal adenoma tissue also revealed high intensity, which revalidates the essential role of LHCGR in this particular condition. Recently, the cAMP pathway has been recognized as the functional pathway downstream to LHCGR in pregnancy-induced CS. Anne Trinh et al. [14] described a case developing Cushing's syndrome in pregnancy with an adrenal tumor harboring both LHCGR expression and a codon 201 mutation in the G alpha subunit in the cAMP pathway (GNAS), and characterized the underlying molecular pathogenesis as aberrant amplification of cAMP signaling pathway subsequent to LHCGR overexpression. Furthermore, in a case of pregnancy-induced CS with bilaterally enlarged adrenals reported by Plockinger $U$ et al., hCG stimulation of cultured primary adrenal cells overexpressing LHCGR significantly elicited increased cAMP production and resulted in glucocorticoids synthesis, suggesting the possible role of LH/hCG-stimulated transformation of LHCGR-positive undifferentiated subcapsular cells (presumably adrenocortical progenitors) into LHCGR-positive hyperplastic cortical cells responding to $\mathrm{LH} / \mathrm{hCG}$ stimulation with ACTHindependent hormonal production [15]. Taken together, these findings indicated the essential role of the aberrant activation of LHCGR coupled to an up-regulated cAMP pathway in the pathophysiology of pregnancy-induced CS. Unlike the constitutive activation of cAMP/PKA signaling due to a high frequency (35-65\%) of somatic mutations affecting PRKACA in CPAs [16, 17], LHCGRmediated signaling may serve as an exceptional way to activate the cAMP pathway, leading to hCG-dependent cortisol excess. A reasonable assumption is that persistently increased hCG level in early pregnancy activates aberrantly upregulated LHCGR, subsequently triggers the downstream signal transduction, and thus enhances the production of glucocorticoids. After delivery, when endogenous cortisol secretion returned to normal, the significant cortisol increase evoked by exogenous hCG during non-pregnancy state indicated the positive response of LHCGR to hCG stimulus.

$\mathrm{ACTH}$ is the principal regulator of adrenal cortisol production and signals through reacting on its receptor, MC2R. MC2R, a highly expressed GPCR on the surface of normal adrenocortical cells which binds one sole ligandACTH [17], was negative for IHC staining in our case, suggesting that MC2R may not be required for the excessive cortisol secretion in this condition. Considering that elevated estrogen during pregnancy could also potentially contribute to the activation of cAMP pathway through reacting on corresponding GPCR-GPER-1, IHC was performed on the tumor tissue to detect the expression of GPER-1 and the staining for GPER-1 was also negative. As a recently identified GPCR, GPER-1 has been reported to modulate aldosterone synthesis in aldosterone producing adenoma cells [25], but whether GPER-1 plays a role in the excessive hormone production and tumor formation of CPA remains to be elucidated.

In conclusion, we describe a case of pregnancyinduced CS with an adrenal adenoma overexpressing LHCGR and discuss its underlying pathogenetic mechanism on the basis of previous findings and our IHC results. Stimulation test with exogenous hCG after parturition is necessary to identify pregnancy-induced CS. LHCGR-mediated activation of cAMP signaling pathway may serve as an essential role in the pathogenesis of this particular condition.

\section{Abbreviations \\ 24 h UFC: 24 h free urinary cortisol; ACTH: Adrenocorticotropic hormone; CAMP: Cyclic adenosine monophosphate; CBG: Corticosteroid-binding globulin; CPA: Cortisol-producing adrenal adenoma; CS: Cushing's syndrome; DEXA: Desamethasone; DST: Desamethasone overnight suppression test; GA: Gestational age; GDM: Gestational diabetes mellitus; GPCR: G-protein- coupled receptor; GPER-1: G protein-coupled receptor-1; GNAS: G alpha subunit in the CAMP pathway; hCG: Human choriogonadotropin; HPA axis: Hypothalamic-pituitary-adrenal axis; IHC: Immunohistochemistry; LH: Luteinizing hormone; LHCGR: Luteinizing hormone/human choriogonadotropin receptor; MC2R: Melanocortin 2 receptor; MRI: Magnetic resonance imaging; OGTT: Oral glucose tolerance test; PKA: Protein kinase A; PRKACA: CAMP dependent protein kinase $A$}

\section{Acknowledgements}

Not applicable.

\section{Authors' contributions}

SL and CY collected, analyzed and interpreted the clinical data, performed pathological analysis, reviewed the literature and drafted the manuscript. JF, YY and $X L$ participated in analysis and interpretation of the data. YG and SZ contributed to diagnosis and management of the patient, and critically revised the manuscript. All authors read and approved the final manuscript.

\section{Funding}

This study was supported by National Natural Science Foundation of China (81970683) to S. Zhang and the Natural Science Foundation of Guangdong Province (2018A030313596) to Y. Guo, which were mainly for the collection, pathological analysis, and interpretation of data.

\section{Availability of data and materials}

All data generated or analysed during this study are included in this published article [and its supplementary information files].

Ethics approval and consent to participate

Not applicable.

\section{Consent for publication}

Written informed consent was obtained from the patient for publication of this Case report and any accompanying images. A copy of the written consent is available for review by the Editor of this journal.

Competing interests

The authors declare that they have no competing interests. 
Received: 10 March 2020 Accepted: 27 April 2020

Published online: 11 May 2020

\section{References}

1. Wieland RG, Shaffer MB Jr, Glove RP. Cushing's syndrome complicating pregnancy. A case report. Obstet Gynecol. 1971;38(6):841-3.

2. Reschini E, Giustina G, Crosignani PG, D'Alberton A. Spontaneous remission of Cushing syndrome after termination of pregnancy. Obstet Gynecol. 1978; 51(5):598-602.

3. Aron DC, Schnall AM, Sheeler LR. Spontaneous resolution of Cushing's syndrome after pregnancy. Am J Obstet Gynecol. 1990;162(2):472-4.

4. Close CF, Mann MC, Watts JF, Taylor KG. ACTH-independent Cushing's syndrome in pregnancy with spontaneous resolution after delivery: control of the hypercortisolism with metyrapone. Clin Endocrinol. 1993;39(3):375-9.

5. Caticha O, Odell WD, Wilson DE, Dowdell LA, Noth RH, Swislocki AL, Lamothe JJ, Barrow R. Estradiol stimulates cortisol production by adrenal cells in estrogen-dependent primary adrenocortical nodular dysplasia. J Clin Endocrinol Metab. 1993;77(2):494-7.

6. Wallace C, Toth EL, Lewanczuk RZ, Siminoski K. Pregnancy-induced Cushing's syndrome in multiple pregnancies. J Clin Endocrinol Metab. 1996; 81(1):15-21.

7. Lacroix A, Hamet P, Boutin JM. Leuprolide acetate therapy in luteinizing hormone--dependent Cushing's syndrome. N Engl J Med. 1999;341(21): 1577-81.

8. Kasperlik-Zaluska AA, Szczupacka I, Leszczynska-Bystrzanowska J, DrusPrzybyszewska G. Pregnancy-dependent Cushing's syndrome in three pregnancies. Bjog. 2000;107(6):810-2.

9. Hana V, Dokoupilova M, Marek J, Plavka R. Recurrent ACTH-independent Cushing's syndrome in multiple pregnancies and its treatment with metyrapone. Clin Endocrinol. 2001;54(2):277-81.

10. Wy LA, Carlson HE, Kane P, Li X, Lei ZM, Rao CV. Pregnancy-associated Cushing's syndrome secondary to a luteinizing hormone/human chorionic gonadotropin receptor-positive adrenal carcinoma. Gynecol Endocrinol. 2002;16(5):413-7.

11. Chui MH, Ozbey NC, Ezzat S, Kapran Y, Erbil Y, Asa SL. Case report: adrenal LH/hCG receptor overexpression and gene amplification causing pregnancy-induced Cushing's syndrome. Endocr Pathol. 2009;20(4):256-61.

12. Rask E, Schvarcz E, Hellman P, Hennings J, Karlsson FA, Rao CV. Adrenocorticotropin-independent Cushing's syndrome in pregnancy related to overexpression of adrenal luteinizing hormone/human chorionic gonadotropin receptors. J Endocrinol Investig. 2009:32(4):313-6.

13. Achong N, D'Emden M, Fagermo N, Mortimer R. Pregnancy-induced Cushing's syndrome in recurrent pregnancies: case report and literature review. Aust N Z J Obstet Gynaecol. 2012;52(1):96-100.

14. Trinh A, Chan I, Alexiadis M, Pell M, Kumar B, Fuller PJ. Adrenal Cushing's syndrome in pregnancy: clinical and molecular characterisation of a case. Obstet Med. 2016;9(1):43-5.

15. Plockinger U, Chrusciel M, Doroszko M, Saeger W, Blankenstein O, Weizsacker K, Kroiss M, Hauptmann K, Radke C, Pollinger A, et al. Functional implications of $\mathrm{LH} / \mathrm{hCG}$ receptors in pregnancy-induced Cushing syndrome. J Endocr Soc. 2017;1(1):57-71.

16. Calebiro D, Hannawacker A, Lyga S, Bathon K, Zabel U, Ronchi C, Beuschlein F, Reincke M, Lorenz K, Allolio B, et al. PKA catalytic subunit mutations in adrenocortical Cushing's adenoma impair association with the regulatory subunit. Nat Commun. 2014:5:5680.

17. Calebiro D, Di Dalmazi G, Bathon K, Ronchi CL, Beuschlein F. CAMP signaling in cortisol-producing adrenal adenoma. Eur J Endocrinol. 2015;173(4):M99_ 106.

18. Lindsay JR, Nieman LK. The hypothalamic-pituitary-adrenal axis in pregnancy: challenges in disease detection and treatment. Endocr Rev. 2005:26(6):775-99.

19. Nieman LK, Biller BM, Findling JW, Newell-Price J, Savage MO, Stewart PM, Montori VM. The diagnosis of Cushing's syndrome: an endocrine society clinical practice guideline. J Clin Endocrinol Metab. 2008;93(5):1526-40.

20. Brue T, Amodru V, Castinetti F. Management of endocrine disease: management of Cushing's syndrome during pregnancy: solved and unsolved questions. Eur J Endocrinol. 2018;178(6):R259-r266.

21. Lindsay JR, Jonklaas J, Oldfield EH, Nieman LK. Cushing's syndrome during pregnancy: personal experience and review of the literature. J Clin Endocrinol Metab. 2005;90(5):3077-83.
22. Affinati AH, Auchus RJ. Endocrine causes of hypertension in pregnancy. Gland Surg. 2020:9(1):69-79.

23. Machado MC, Fragoso M, Bronstein MD. Pregnancy in patients with Cushing's syndrome. Endocrinol Metab Clin N Am. 2018:47(2):441-9.

24. Andreescu CE, Alwani RA, Hofland J, Looijenga LHJ, de Herder WW, Hofland $L J$, Feelders RA. Adrenal Cushing's syndrome during pregnancy. Eur J Endocrinol. 2017;177(5):K13-k20.

25. Caroccia B, Seccia TM, Campos AG, Gioco F, Kuppusamy M, Ceolotto G, Guerzoni E, Simonato F, Mareso S, Lenzini L, et al. GPER-1 and estrogen receptor-beta ligands modulate aldosterone synthesis. Endocrinology. 2014; 155(11):4296-304

\section{Publisher's Note}

Springer Nature remains neutral with regard to jurisdictional claims in published maps and institutional affiliations.
Ready to submit your research? Choose BMC and benefit from:

- fast, convenient online submission

- thorough peer review by experienced researchers in your field

- rapid publication on acceptance

- support for research data, including large and complex data types

- gold Open Access which fosters wider collaboration and increased citations

- maximum visibility for your research: over $100 \mathrm{M}$ website views per year

At BMC, research is always in progress.

Learn more biomedcentral.com/submissions 